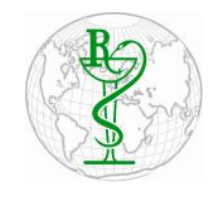

INDO GLOBAL JOURNAL OF

PHARMACEUTICAL SCIENCES

ISSN 2249- 1023

\title{
Phytochemical Screening, Chromatographic Studies and Antibacterial Activity of Eclipta alba L. Leaves Extracts
}

\author{
Abubakar Abdulhamid ${ }^{1}$, Innocent Chibuokem Onyenonachi ${ }^{1}$, Amar Mohamed Ismail ${ }^{2 *}$ \\ ${ }^{1}$ Department of Biochemistry, Faculty of Science, Kebbi State University of Science and Technology, Kebbi State-Nigeria \\ ${ }^{2}$ Department of Biochemistry and Molecular Biology, Faculty of Science and Technology, University of Al-Neelain, Khartoum-Sudan
}

\begin{abstract}
Address for
Correspondance

Amar Mohamed

Ismail,

amarqqqu@yaho

$\underline{\text { o.com }}$

Received:

27.03.2017

Accepted:

27.08.2017

ABSTRACT: The current study aim to evaluate the antibacterial activity of column chromatographic fractions of Eclipta alba L. extracts. Leaves were extracted using water, methanol, chloroform and n-hexane as solvents. The phytochemical screening of the solvent extracts was carried out using standard methods while the antibacterial activity was tested using disc diffusing method. The result for the phytochemical screening showed the presence of reducing sugars, cardiac glycosides, saponins, terpenoids, flavonoids, alkaloids and tannins. Ethanolic extract showed a higher degree of inhibition followed by the aqueous extract, petroleum ether as well as the hexane extracts at a concentration $100 \mathrm{mg} / \mathrm{ml}$. The ethanolic extract was further subjected to fractionation by column and thin layer chromatography after which seven fractions (F1 - F7) were obtained and tested against the same strains of bacteria. Fractions F2, F5 and F6 had inhibitory effect against the bacterial species used compared to other fractions. The data suggested, the traditional use of Eclipta alba L. leaf extracts in the treatment of dysentery, gastroenteritis, typhoid fever and wound infections. @ 2017 iGlobal Research and Publishing Foundation. All rights reserved.
\end{abstract}

Keywords Eclipta alba; Antibacterial Activity; Phytochemicals; Methanolic Extract; Zone of Inhibition.

\section{INTRODUCTION}

Medicinal plants are plants that have a recognized medical use. They range from those used in the production of mainstream pharmaceutical products to plants used in herbal medicinal preparations [1]. Herbal medicine is one of the oldest forms of medical treatment in human history and could be considered one of the forerunners of the modern pharmaceutical trade. Plants that have medical uses can be found growing in many settings all over the world. Many plants contain pharmacologically active compounds that can be accessed by making teas, tisanes and other preparations. Plants can also be blended with each other to achieve a desired outcome or processed to make homeopathic medicines, along with medicines designed for topical application, such as oils and creams [2]. Bacteria causes a significant amount of illnesses in our society and these illnesses if not treated can be life threatening. Moreover, emergence of multiple drug resistant strains of microorganisms due to indiscriminate use of antibiotics to treat infectious diseases has generated a renewed interest in herbal medicine [3]. Antibacterial potential of different medicinal plants is being extensively studied all over the world [4]. Eclipta alba L. is an annual herbaceous plant, commonly known as "false daisy". It is an erect or prostrate, much branched, roughly hairy, rooting at the nodes; the leaves are opposite, sessile and lanceolate. It belongs to the family Asteraceae. Eclipta alba $L$. is a straggling herb of about $50 \mathrm{~cm}$ high, of waste moist sites occurring throughout the region of the tropics and part of the subtropics. Eclipta alba $L$. is known for its medicinal values in unconventional system of herbal medicine. Eclipta alba $L$. is reported to possess hepatoprotective, antibacterial, anti-inflammatory, analgesic, immuno-modulatory, antiviral, leprosy, asthma and bronchitis activities $[5,6]$. The aim of this study is to justify the claimed uses of Eclipta alba in different traditional medicinal practices by accessing the presence of phytochemical constituents responsible for the therapeutic 
Indo Global Journal of Pharmaceutical Sciences, 2017; 7(2): 143-147

potential of the plant and to evaluate the effect of different solvents extracts on the antibacterial activity of the plant against some pathogenic bacteria.

\section{MATERIALS AND METHODS}

\section{Sample Collection and Identification}

Fresh leaves of Eclipta alba $L$. was collected from a farm land belonging to Labana Global Ventures in Aliero Local Government Kebbi State, Nigeria. The plant was identified by a Botanist. The specimen has been allotted a voucher sample and kept at Department of Biological Sciences, Kebbi State University of Science and Technology Aliero, Kebbi State, Nigeria.

\section{Preparation and Extraction of Plant Materials}

The leaves were dried at room temperature and then grounded to fine powder using a sterile Electric blender. One hundred grams $(100 \mathrm{~g})$ of the dried and powdered plant was extracted using water, ethanol, petroleum ether and n-hexane as solvents for $72 \mathrm{hrs}$ respectively. Each of the plant extract was filtered and concentrated using a water bath.

\section{Phytochemical Screening}

Qualitative phytochemical screening was performed for the detection of reducing sugars, alkaloids, saponins, flavonoids, terpenoids, tannins, cardiac glycosides and anthraquinone with the use of the standard methods $[7,8,9]$.

\section{Antibacterial Activity}

The extracts obtained were screened for their antibacterial activity in vitro by disc diffusion method [10]. The paper discs (6 mm diameter, Whatman No. 1 filter paper) containing $100 \mathrm{mg} / \mathrm{ml}$ plant extracts were dried and placed aseptically on the agar surface with the help of a sterile forceps and paper discs were pressed slightly with the forceps to make complete contact with the surface of the medium. The plates were kept at room temperature for half an hour and subsequently incubated for a period of 24 hours at $37^{\circ} \mathrm{C}$ and observed for zone of inhibition. The inhibition zones around each disc were measured in millimeter and the assay was carried out three times for each extract. The results were recorded by measuring the zone of growth inhibition surrounding the disc.

\section{Fractionation of the Ethanolic Extract of Eclipta alba $L$. Column Chromatography}

Column chromatography was used to achieve the fractionation of the plant extract. $2 \mathrm{~g}$ of the extract was subjected to column chromatography to separate the extract into various component fractions. Silica gel of 60-120 mesh was used as the stationary phase, and the mobile phase was chloroform: ethanol. In setting up of the column chromatography, the lower part of the glass column was stocked with a glass wool with the aid of glass rod. The slurry was prepared by mixing $25 \mathrm{~g}$ of silica gel and $250 \mathrm{ml}$ of the solvent system chloroform: ethanol was poured down carefully into the column, the tap of the glass column was left open to allow flow of the solvent system into conical flask below, the set-up was seen to be in order when the solvent system drain freely without carrying the silica gel or glass wool along, at the end of the packing, the tap was locked, the column was allowed to settle, after which clear solvent was allowed to drain down to the silica gel meniscus. The column was set up using wet packing method [11].

\section{Thin Layer Chromatography (TLC)}

Each fraction that were eluted was subjected to thin layer chromatography (TLC) as per conventional one dimensional ascending method using pre-coated silica gel plates. Plate markings were made with soft pencil. A Glass capillary (1microlitre) was used to spot the samples at an interval of $1 \mathrm{~cm}$ on the thin layer chromatographic plate and was allowed to dry. The chromatographic tank containing the solvent system of Chloroform: Ethanol: Hexane (6:3:1) was allowed for $20 \mathrm{~min}$ to pre-saturate. The thin layer chromatographic plate was then lowered down into the chromatographic tank. The tank was tightly covered to prevent escape of the solvents. After the solvent have travelled a distance from the origin, the plant components separated, the plates were removed and allowed to dry. Another chromatographic tank containing iodine crystal which was well covered was allowed for 30min to pre-saturate. The chromatographic plates were inserted into the pre-saturated iodine crystal chromatographic tank for visibility (clear resolution) of bands. After the thin layer chromatography was done, the separated plant components were clearly seen and their retardation factor was calculated using the formula:

$$
\mathrm{R}_{f}=\frac{\text { Distance travelled by the solute }}{\text { Distance travelled by the solvent front on TLC plate }}
$$

\section{Antibacterial Activity of Column Fractions of Ethanolic Extract of Eclipta alba $L$.}

Seven (7) fractions were obtained and were screened for their antibacterial activity by disc diffusion method (described previously).

\section{RESULTS AND DISCUSSION}

The result of the qualitative phytochemical screening of Eclipta alba $L$. leaves extracts showed the presence of some of the phytochemicals tested as shown in Table $\mathbf{1}$ below. While 
Indo Global Journal of Pharmaceutical Sciences, 2017; 7(2): 143-147

the result for the antibacterial activity of leave extracts of of column fractions (F1 - F7) of crude methanolic extract is shown on Table 3.

Eclipta alba is presented on Table $\mathbf{2}$ and antibacterial activity

Table 1: Phytochemical Constituent Present in Eclipta alba L. Leaves Extracts.

\begin{tabular}{lcccc}
\hline \multicolumn{1}{c}{ Phytochemical Constituents } & Ethanol extract & Petroleum ether & Hexane & Water \\
\hline Reducing sugar & + & + & - & + \\
Saponins & + & + & + & + \\
Tannins & + & + & - & - \\
Flavonoids & + & - & - & + \\
Terpenoids & + & + & + & + \\
Alkaloids & + & - & - & + \\
Anthraquinones & - & - & - & - \\
Cardiac glycosides & + & - & - & - \\
\hline
\end{tabular}

Key: $+=$ detected,$-=$ not detected

Table 2: Antibacterial activity of crude extracts of Eclipta alba $L$.

Zones of inhibition (mm)*

\begin{tabular}{lccccc}
\cline { 2 - 6 } Bacteria & Ethanol & Pet. Ether & n-Hexane & Aqueous & Cipro. \\
& & & & \\
\hline E. coli & $15.00 \pm 0.40$ & $12.80 \pm 0.04$ & $4.70 \pm 0.05$ & $13.0 \pm 0.08$ & $25.00 \pm 0.00$ \\
S. aureus & $11.80 \pm 0.30$ & $7.80 \pm 0.02$ & $10.30 \pm 0.09$ & $9.30 \pm 0.02$ & $22.90 \pm 0.50$ \\
S. typhi & $10.00 \pm 0.00$ & $8.80 \pm 0.02$ & $4.50 \pm 0.08$ & $3.70 \pm 0.06$ & $19.50 \pm 0.04$ \\
B. subtilis & $13.30 \pm 0.02$ & $12.20 \pm 0.02$ & $11.20 \pm 0.02$ & $9.80 \pm 0.05$ & $24.60 \pm 0.04$ \\
\hline
\end{tabular}

Note: Values are presented as mean \pm standard deviation of three replicates.

Table 3: Antibacterial activity of column fractions (F) of Eclipta alba $L$.

\begin{tabular}{ll} 
Column fractions $\quad$ Organisms/Zone of Inhibition (in mm) \\
\hline
\end{tabular}
E. coli
S. aureus
S. typhi
B. subtilis

F1

F2

$2.33 \pm 0.35$

$6.23 \pm 0.05$

F3

F4

F5

$5.32 \pm 0.49$

$\begin{array}{ll}- & 4.87 \pm 0.05\end{array}$

F6

$3.97 \pm 0.36$

$2.22 \pm 0.78$

$2.00 \pm 0.00$

Note: Values are presented as mean \pm standard deviation of three replicates. 
Indo Global Journal of Pharmaceutical Sciences, 2017; 7(2): 143-147

In the present study, phytochemical screening for all the four extracts showed the presence of some metabolites. The result showed the presence of alkaloids, flavonoids, tannins, saponins, cardiac glycosides, terpenoids and absence of antraquinones in the Eclipta alba $L$. ethanolic extract which supports the work [12]. Secondary metabolites are known to show medicinal and physiological activity while their occurrence and activity varies from plant to plant [8].

The presence of alkaloids, saponins, tannins and terpenoids in the leaves extracts of Eclipta alba $L$. has medicinal implications. These phytochemicals are well known for their biological activity. Tannins were reported to play a role as antifungal, antibacterial, astringent and antibiotic [13,14]. Tannins were also found to form irreversible complexes with proline-rich proteins leading to the inhibition of cellular protein synthesis.

In addition to antimicrobial activity exhibited by tannins, they also react and form complex with proteins to provide the typical tanning effect. This is important medicinally for the treatment of inflamed or ulcerated tissues [15]. Tanninscontaining herbs as their main component are astringent in nature and are used in the treatment of intestinal disorders such as diarrhoea and dysentery, thus exhibiting antimicrobial activity. Terpenoids also act as antibiotics to protect plants from pathogenic microorganisms [16]. Flavonoids are a major group of phenolic compounds reported for their antiviral [17], antimicrobial [18] and spasmolytic properties [19].

The results obtained from the antibacterial activity of the four extracts showed that ethanolic extract has the highest antibacterial activity against all the tested organisms compared to other extracts (table 2). Hence, ethanolic extract was subjected to column and Thin Layer Chromatographies, after which six fractions were obtained. The antibacterial activity of the six fractions on test organisms showed that fractions 1,3 and 4 showed no antibacterial activity, while fractions 2, 5 and 6 showed varied antibacterial activitie against the tested bacteria.

The antimicrobial properties of plants have been investigated by a number of studies worldwide and many of them have been used as therapeutic alternatives because of their antimicrobial properties [20]. Plants are the cheaper and safer alternative sources of antimicrobials [21].

It has been previously demonstrated that ethanol extracts contributed much more antibacterial activity than the aqueous extract [22]. The highest antibacterial activity brought about by this solvent might be due to better solubility of the active components in the leaves.

\section{CONCLUSION}

The observed antibacterial activity against tested bacteria is an indication that the plant is a potential source for production of drugs with a broad spectrum of activity. The results of the present study also supports the traditional medicinal application of the plant and suggests that the plant extracts possess compounds with antibacterial properties that can be used as antibacterial agents in novel drugs formulation for the treatment of gastroenteritis, typhoid fever and wound infections. In addition, there is need for the characterization and isolation of the active ingredients.

\section{REFERENCES}

[1] Chopra, R.N., Nayar, S.L., Chopra, I.C. In Glossary of Indian Medicinal Plants. Council of Scientific and Industrial Research, New Delhi (India), 1956; 104.

[2] Gupta, M., Kanti, U., Palla, K., Chandi, C., Manikanda, L., Senthil, G.P. Anticancer Activity of Indigofera aspalathoides and Wedeliacalendulaceae in Swiss Albino Mice. Iranian journal of pharmaceutical research, 2005; 6(2), 141-145.

[3] Chopra, I., Hodgson, J., Metcalf, B., Poste, G. The search for antibacterial agents effective against bacteria resistant to multiple antibiotics. Antimicrob Agents Chemother, 1997; 4:497-503.

[4] Kaur, G.J., Arora, D.S. Antibacterial and phytochemical screening of Anethum graveolens, Foeniculum vulgare and Trachyspermum ammi. BMC Complement Altern Med, 2009; 9(30):1-10.

[5] Leal, L.K, Ferreir, Bezerra, G.A., Matos, F.J., Viana, G.S. (2000). Antinociceptive, Anti-Inflammatory and bronchodilator activities of Brazilian medicinal plants containing coumarin a comparative study. Ethnopharmacology, 2000; 70, 151-159.

[6] Arunachalam, G., Subramanian, N., Pazhani, G.P. and Ravichandran V. Anti-inflammatory activity of methanolic extract of Eclipta prostrata L. (Astearaceae). Afr. J. Pharmacol, 2009; 3(3): 97100

[7] Trease, G.E., Evans, W.C. Pharmacognosy. $11^{\text {th }}$ edn. London: Brailliar Tiridel and Macmillian publishers, 1989.

[8] Sofowora, A. Medicinal plants and Traditional medicine in Africa. $1^{\text {st }}$ edition. Nigeria: Spectrum Books Ltd, 1984.

[9] Harborne, J.D. Phytochemical Methods. A guide to Modern Techniques of Plant Analysis. $1^{\text {st }}$ edition. London: Chapman and Hall Ltd, 1973.

[10] Bauer, A.W., Kirby, W.M.M. and Sherris, J.C. Antibiotic susceptibility testing by a standardized single disk method. Am J Clin Pathol, 1966; 45: 493-496.

[11] Davies, Don R.; Johnson, Todd M. Isolation of Three Components from Spearmint Oil: An Exercise in Column and ThinLayer Chromatography Journal of Chemistry Education, 2007; 84, 34-43.

[12] Hussain I, Khan N, Shanzeb RU, Ahmed S, Khan FA and Yaz S,. Phytochemical, physiochemical and anti-fungal activity of Eclipta alba. Afr J Pharm Pharmacol, 2011; 5(19): 2150-2155.

[13] Akiyama H, Fujii K, Yamasaki O, Oono T, Iwatuski K. Antibacterial action of several tannins against Staphylococcus aureus. Anti. Chemoth. 2001; 48: 487-491. 
Indo Global Journal of Pharmaceutical Sciences, 2017; 7(2): 143-147

[14] Liu S.W, Jiang S.B, Wu S.G. Tannin inhibits HIV-1 entry by targeting gp41. Acta Pharm. Sin., 2004; 25: 213-218.

[15] Mota M.L.R, Thomas G, Barbosa Filho J.M. (1985) Antiinflammatory actions of tannins isolated from the bark of Anacardium occidentale L. J. Ethnopharmacol.1985; 13: 289-300.

[16] Aliyu A.B, Musa A.M, Osnimi J.A, Ibrahim H.A, Oyewale A.O. (2008) Phytochemical analysis and mineral composition of some medicinal plants in northern Nigeria Nigerian J. Pharm. Sci, 2008; 7: 119-125.

[17] Mehrangiz, K.K., Seyed, A.E., Masoud, S.G., Esmaeel, A.S. and Amirhossein, S. Antiviral activities of aerial subsets of Artemisia species against Herpes, 2011;

[18] Maria Lysete, A.B., Maria Raquel, F.L., Lucia, M.C., Vania, S.A., Eliana, M.M.R. and Rosangela, P.L.L. Studies on the antimicrobial activity and brine shrimp toxicity of $\mathrm{Z}$. tuberculosa (Vell.) Bur. (Bignoniaceae) extracts and their main constituents. Ann. Clin. Microb. Antimic, 2009; 8: 16-20.

[19] Julianeli, T.D.L., Jackson, R.G.S., Kelly, S. and Ana, S.S.C. Selective spasmolytic effect of a new furanoflavoquinone derivate from diplotropin on guinea-pig trachea. Journal of Chemical and Pharmaceutical Research, 2011; 3: 249-258.

[20] Adriana, B., Almodovar, A.N.M., Pereiral, C.T., and Mariangela, T.A. Antimicrobial efficacy of Curcuma zedoaria extract as assessed by linear regression compared with commercial mouthrinses. Braz. J. Microbiol, 2007; 38: 440-445

[21] Doughari, J.H., El-mahmood, A.M., and Manzara, S. Studies on the antibacterial activity of root extracts of Carica papaya L. Afri. J Microbiol. Res, 2007; 37-41.

[22] Ezeifeka, G.O., Orji, M.U., Mbata, T.I., and Patrick, A.O. Antimicrobial activities of Cajanusajan, Garciniakol, and Xylopiaaethiopica on pathogenic microorganisms. Biotechnology, 2004; 3(1): 41-43.

Indo Global Journal of Pharmaceutical Sciences( ISSN 22491023 ; UGC Journal No.: 44477; CODEN- IGJPAI; NLM ID: 101610675) indexed and abstracted in EMBASE(Elsevier), UGC Journal List, National Library of Medicine (NLM) Catalog, Elsevier( EMBASE), ResearchGate, Publons, CAS (ACS), Index Copernicus, Google Scholar and many more. For further details, visit http://iglobaljournal.com 